GLOBAL JOURNAL OF ENVIRONMENTAL SCIENCES VOL. 12, 2013: 41-47

COPYRIGHT@ BACHUDO SCIENCE CO. LTD PRINTED IN NIGERIA ISSN 1596-6194

www.globaljournalseries.com, Email: info@globaljournalseries.com

\title{
EFFECT OF INDOMIE INDUSTRIAL EFFLUENT DISCHARGE ON FISH FAUNA OF NEW CALABAR RIVER, PORT HARCOURT
}

\author{
G. N. WOKE, B. B. BABATUNDE AND WOKOMA ALELEYE
}

\begin{abstract}
The effect of Indomie industrial effluent discharge on the fish fauna of New Calabar River was investigated in order to ascertain the influence of BOD, COD, DO, TDS, TSS, pH, salinity, phosphate and temperature on the composition and distribution of fish fauna. The diversity of the fish fauna was found to be poor, only 12 fish species in 6 families were identified. The highest number (10) of fishes was recorded in station 4 while the least number (1) of fishes was observed in station 1 . The fish families were: Cichlidae (38.89\%), Clupidae (33.33\%), Pomadasyidae (16.67\%), Bagridae (11.11\%) while Genidae and Muglidae had zero percentage of fishes in its abundant. The resident fish species (Ethmalosa fimbriata and Tilapia guinensis) were highly adapted to the changes in the study environment and this was dependent on their trophic relationship within the environment. These species had great affinity for indomie industrial waste, because they feed on waste remains, mud/sediment silts and annelids, juveniles of shrimps and crabs. The deterioration of water quality was evident by the high BOD $(12.80 \mathrm{mg} / \mathrm{L}), \operatorname{COD}(130 \mathrm{mg} / \mathrm{L})$, TDS $(37 \mathrm{mg} / \mathrm{L})$, TSS $(62 \mathrm{mg} / \mathrm{L}), \mathrm{pH}(5.2)$, salinity $(50.54 \mathrm{mg} / \mathrm{L})$, phosphate $(0.14 \mathrm{mg} / \mathrm{L})$ and temperature $\left(27^{\circ} \mathrm{C}\right)$ as well as the low dissolved oxygen $(2.8 \mathrm{mg} / \mathrm{L})$ values observed. It was recommended that a routine treatment of the effluent before discharge into the water should be carried out so to maintain safe levels of industrial effluent in the immediate and extended environment.
\end{abstract}

KEYWORDS: Effluent, pollution, environment, fish and fauna.

\section{INTRODUCTION}

Environmental pollution is a global problem which has been with man for a very long time. However, in Nigeria its impact seem to have just been realized. This is attested by the effort of the present government in tackling the issue in recent times. This has led to the establishment of the Federal Environmental Protection Agency (FEPA) by decree number 58 of 1988, saddled with the responsibility of making and implementing environmental laws and standards in order to protect, restore and preserve the
Nigerian environment from all kinds of pollution (Ogan and Nwiika, 1993).

The effect of Indomie effluent on the aquatic environment resulting from pollution have generated a lot of interest in the scientific research on oil pollution. The pollution in the environment is caused by the pollutant. The toxicity of the oil can be interpreted as the toxicity of a complex mixture of organic and inorganic chemical. Studies of some Nigerian rivers by Ajayi and Osibanjo (1981) and Asuquo (1989) reveled that water that was once an abundant natural resource is rapidly becoming scarce in

G. N. Woke, Department of Animal \& Environmental Biology, University of Port Harcourt, Choba, Port Harcourt, Nigeria.

B. B. Babatunde, Department of Animal \& Environmental Biology, University of Port Harcourt, Choba, Port Harcourt, Nigeria.

Wokoma Aleleye, Department of Animal \& Environmental Biology, University of Port Harcourt, Choba, Port Harcourt, Nigeria. 
quantity and the quality is fast deteriorating due to population increase, rapid industrialization and rural/urban migration. Almost all water used by man is returned as waste water and requires proper disposal to prevent it from reaching and contaminating water resources. In most cases, this is not practiced due largely to technical and economic reasons (Asuquo, 1989).

The organic pollution and influence of seasonal changes as well as industrial effluent on organic load of the river was also reported (Odokuma and Okpokwasili, 1997). Ten years later, Odokuma and ljeomah (2003) on heavy metal resistance among bacterial populations of the New Calabar River.

The concern over water quality relates not just to the water itself, but also to the danger of diffusion of toxic substances into other ecosystems (Pretorius, 2000, Bezuidenhont et al, 2002). The aquatic environment for living organisms can be affected and bioaccumulation of harmful substances in the water-dependent food chain can occur (Alam et al, 2006). Surface water is vulnerable to pollution from untreated industrial effluents and municipal wastewater, run-off from chemical fertilizers and pesticides, as well as oil and lube spillage in the coastal area from the operation of sea and river ports (Odukuma and Okpokwasili, 1997; Krantz and Kifferstein, 1998). Similarly, increase of faecal pollution in source water is also a problem in developing as well as developed countries (Sinton et al, 1993).

Dissolved nutrient in natural waters are usually low (Asuquo and Okorie, 1987) and composition of surface waters is derived from the atmosphere, soil and rock sources. The relative contribution to surface waters from each of those sources is a function of the climate being modified increasingly by human activities (Alam et al, 2006).

Multiple antibiotic resistance in bacterial populations of some lower Niger Delta rivers including the New Calabar River were exported in the previous study (Ogan and Nwiika, 1993). This resistance was attributed to indiscriminate waste disposal in the fresh and brackish water-bodies.

Portable water for domestic use should be free from pathogenic microorganisms and toxic substances such as heavy metals and hydrocarbons. Drinking water should be odourless, tasteless, colourless and devoid of particulate matter (Reid et al, 1979). The protection of public health requires that people be supplied with water of adequate quality which satisfies the minimum quality standard. Pollution of fresh water bodies (rivers, lakes, ponds and streams) by nutrients is mostly experienced as a result of industrial discharge, municipal domestic sewage disposals, surface runoff from agricultural kinds, underground water and salt water intrusion and inundation (Asuquo and Okorie, 1987).

The New Calabar River is subjected to industrial effluent of the Indomie load arising from effluent discharge and some other forms of anthropogenic functions. The continuous discharge of these Indomie wastes into the water and lack of information on the responses of aquatic biota (fish fauna) to the waste, necessitate this study. Therefore, the aim of this study is to carry out water quality assessment of New Calabar River where the industrial effluent of the Indomie industry is discharge, to ascertain the possible effects on the fish fauna.

\section{STUDY AREA}

The sources of New Calabar River run between Ibea and Ndele and this is about $5^{\circ} 10^{\prime} \mathrm{N}$ and $6^{\circ} 45^{\prime} \mathrm{E}$. The river flows southwards into the Atlantic ocean near Bonny and it contains fresh water till Akpor, after which it becomes brackish.

The river is characterized by low sea inflow and high fresh water input from adjoining swamp forests and municipal sewers within the Choba area of Port Harcourt. The river is the main source of water for domestic purposes, traditional, recreational and commercial use as well as industrial. Within the area of study, the river receives discharge effluents from the community drainage systems, food processing company (Indomie), oil drilling company (wilbros) and run-off from large agricultural fields. For the purpose of this study, four stations were selected along the New Calabar River.

Station 1 (Indomie company): This is the point source where wastes from Indomie company is discharged into the water body. Station 2: Is $10 \mathrm{~m}$ upstream from the source. Station 3 (Choba market): Is $10 \mathrm{~m}$ downstream from the source. Station 4 (Choba bridge): is $30 \mathrm{~m}$ downstream from the source and it serves as a control from the source point. The water flows from station 2 to 1 and $4-3$. At high tides, the water flows upstream and when the direction of the water flow changes instead of flowing at the normal direction, the flow will be backwards. Hence at low tides, the water flow changes its normal direction. 


\section{MATERIALS AND METHODS}

\section{Collection of Samples}

Fish samples were collected from each of the sampling stations. A dugout canoe with paddles was used for sampling at the various stations. Traw/nets of $60 \mathrm{~mm}$ and stow nets of $50 \mathrm{~m}$ wide were used along the course of the river, large species as well as small species of fish were caught or sampled. The fishing effort was the same in each station sampled. All fishes sampled were taken to the laboratory for immediate preservation with $10 \%$ formalin solution in labelled plastic containers. In the laboratory, fish were sorted, identified and counted using appropriate keys (FAO, 1990; Schnelder, 1996). Each sampling operation lasted for about three hours. The fishes caught per throw of net were recorded for that location. The total fish catch per station was pooled to obtain the average catch categorized by species per station/month. Their relative abundances were calculated as percentage of the total catch, using

$$
\text { Density }=\frac{\text { Total number of animals }}{\text { Area of sample unit }}
$$

Physico-chemical parameters such as Biochemical Oxygen demand $\left(\mathrm{BOD}_{5}\right)$, Chemical Oxygen demand (COD), dissolved oxygen (DO), total suspended solids (TSS), total dissolved solids (TDS), salinity, phosphate, $\mathrm{pH}$ and temperature $(\mathrm{OC})$ were used to determine the water quality and effects of Indomie waste effluent. Water samples for the determination of $\mathrm{BOD}_{5}, \mathrm{COD}, \mathrm{DO}, \mathrm{TSS}$, TDS, salinity, $\mathrm{pH}$ and temperature were collected for each sample station. The Azide modification method was used to determine the initial dissolved oxygen (DO) (APHA, 1998). BOD 5 was computed from the difference between initial and final DO. Chemical oxygen demand is a measure of the oxygen equivalent of that portion of the organic matter in a sample that is susceptible to oxidation by a strong chemical oxidant was measured using (APHA, 1998). Temperature measurement of surface water was carried out with a mercury in glass thermometer (centigrade ${ }^{0} \mathrm{C}$ ), whereas a measuring cylinder was used to measure TSS (APHA, 1998).

\section{RESULTS}

A total of 12 fish species belonging to 6 families were identified (see checklist of the fauna is presented in Table 1). The total number of organism per stations and relative species richness are show in Tables 2, 3 and 4 . Identification of fish species was carried out based on keys provided by the following: Schneider (1990) and Tobor (1968).

Table 1: Fish fauna collected from New Calabar River, Port Harcourt

\begin{tabular}{|c|c|c|}
\hline $\mathbf{S} / \mathbf{N}$ & Fish families & Species \\
\hline 1. & Bagridae & Chrysichthys aurantus \\
\hline 2. & Cichlidae & $\begin{array}{l}\text { Sarotherodon melanotheron } \\
\text { Tilapia guinensis }\end{array}$ \\
\hline 3. & Clupidae & $\begin{array}{l}\text { Ethmalosa fimbriata } \\
\text { Sardinella maderensis }\end{array}$ \\
\hline 4. & Gerridae & $\begin{array}{l}\text { Eucinostomus melanopterus } \\
\text { Geris nigri }\end{array}$ \\
\hline 5. & Muglidae & $\begin{array}{l}\text { Liza falcipinnis } \\
\text { Liza grandisquanis }\end{array}$ \\
\hline 6. & Pomadasyidae & $\begin{array}{l}\text { Pomadasys rogerii } \\
\text { Pomadasys jubelini }\end{array}$ \\
\hline
\end{tabular}


Table 2: Catch statistics from the different sampling stations

\begin{tabular}{|c|c|c|c|c|c|c|}
\hline \multirow[t]{2}{*}{$\mathbf{S} / \mathbf{N}$} & \multirow[t]{2}{*}{ Species } & \multicolumn{5}{|c|}{ Stations } \\
\hline & & 1 & 2 & 3 & 4 & Total \\
\hline 1. & Chrysichthys auratus & - & - & - & 2 & 2 \\
\hline 2. & Chrysichthys longifilis & - & - & - & - & - \\
\hline 3. & Sarotherodon melanotheron & - & - & - & 2 & 2 \\
\hline 4. & Tilapia guinensis & - & - & 2 & 3 & 5 \\
\hline 5. & Ethmalosa fimbriata & - & 1 & 2 & 2 & 5 \\
\hline 6. & Sardinella maderensis & - & 1 & - & - & 1 \\
\hline 7. & Geris nigri & - & - & - & - & - \\
\hline 8. & Eueinostomus melanopterus & - & - & - & - & - \\
\hline 9. & Liza falcipinnis & - & - & - & - & - \\
\hline 10. & Liza grandisquanis & - & - & - & - & - \\
\hline 11. & Pomadasys rogerri & 1 & - & - & 1 & 2 \\
\hline \multirow[t]{2}{*}{12.} & Pomadasys jubelini & - & - & 1 & - & 1 \\
\hline & & 1 & 2 & 5 & 10 & 18 \\
\hline
\end{tabular}

Table 3: Percentage composition of families and species in each class of fish fauna collected

\begin{tabular}{|c|c|c|c|c|}
\hline Families & $\begin{array}{l}\begin{array}{l}\text { Total no. of } \\
\text { families }\end{array} \\
\text { la }\end{array}$ & $\begin{array}{l}\text { Total no. of } \\
\text { species }\end{array}$ & $\begin{array}{l}\text { Percentage } \\
\text { composition }\end{array}$ & species \\
\hline Bagridae & 1 & 2 & 16.7 & \\
\hline Cichlidae & 1 & 2 & 16.7 & \\
\hline Clupidae & 1 & 2 & 16.7 & \\
\hline Gerridae & 1 & 2 & 16.7 & \\
\hline Muglidae & 1 & 2 & 16.7 & \\
\hline Pomadasyidae & 1 & 2 & 16.7 & \\
\hline Total & 6 & 12 & 100 & \\
\hline
\end{tabular}

Table 4: Percentage abundance of each class of individual fish fauna

\begin{tabular}{|c|c|c|c|}
\hline Families & $\begin{array}{l}\text { Total no. of } \\
\text { individual }\end{array}$ & $\begin{array}{l}\text { Mean total no. of } \\
\text { individual }\end{array}$ & $\begin{array}{l}\text { Percentage } \\
\text { abundance }\end{array}$ \\
\hline Bagridae & 2 & 1.0 & 11.11 \\
\hline Cichlidae & 7 & 3.5 & 38.89 \\
\hline Clupidae & 6 & 3.0 & 33.33 \\
\hline Pomadasyidae & 3 & 1.5 & 16.67 \\
\hline Total & 18 & 9.0 & 100.00 \\
\hline
\end{tabular}

Tilapia guinensis and Ethmalosa fimbriata were the most dominant species. Both has the total number of five (5) species in number while Chrysichthys auratus and Sarotherodon melanotheron had two (2) species each. Sardinella maderensis and Pomadasys jubelini are represented by one species.

The highest number of Ichthyo-fauna (10 individual fishes) were caught in station 4 where the water was always full, clear and well oxygenated and it served as a control site in the study area.
This observation gave an indication of their sensitivity to environmental stress and fish abundance resulted from the absence of Indomie waste dump. The lowest number of organisms was recorded in station $1 \& 2$ which indicated high level of pollution from Indomie waste metabolites and heavy metals that is associated with the station (Table 2). Stations 3 recorded total number of five species, probably because the fishes avoided areas with heavy organic wastes dumps, clouded by sediment silt/organic remains, low salinity, high concentration of 
phosphate, and low dissolved oxygen that may be present at the other polluted stations.

The family Cichlidae (Sarotherodon melanotheron and Tilapia guinensis) was the most abundant fish fauna. This class constituted $38.89 \%$ of the total fishes caught during the study. Other groups included Clupidae (Ethmalosa fimbriata and Sardinella maderensis) $33.33 \%$, Pomadasyidae (Pomadasys roferii and Pomadasys jubelini species) $16.67 \%$, Bagridae (Chrysichthys aurantus and Chrysichthys longifilis species) had $11.11 \%$.

Table 5: The level of BOD, COD, DO, TDS, TSS, pH, salinity, phosphate and temperature on the

\begin{tabular}{lllll}
\multicolumn{5}{c}{ distribution of fish fauna } \\
\hline Samples/Station & $\mathbf{1}$ & $\mathbf{2}$ & $\mathbf{3}$ & $\mathbf{4}$ \\
\hline BOD $(\mathrm{mg} / \mathrm{L})$ & 7.36 & 11.52 & 14.72 & 12.80 \\
$\mathrm{COD}(\mathrm{mg} / \mathrm{L})$ & 20 & 90 & 110 & 130 \\
DO $(\mathrm{mg} / \mathrm{L})$ & 2.8 & 10 & 12 & 15 \\
TDS $(\mathrm{mg} / \mathrm{L})$ & 34 & 36 & 37 & 31 \\
TSS $(\mathrm{mg} / \mathrm{L})$ & $51 \mathrm{mg} / \mathrm{L}$ & $49 \mathrm{mg} / \mathrm{L}$ & $56 \mathrm{mg} / \mathrm{L}$ & $62 \mathrm{mg} / \mathrm{L}$ \\
$\mathrm{pH}$ & 5.0 & 5.1 & 5.1 & 5.2 \\
Salinity $(\mathrm{mg} / \mathrm{L})$ & 38.99 & 40.43 & 50.54 & 44.76 \\
Phosphate (mg/L) & 0.08 & 0.14 & 0.139 & 0.11 \\
Temperature (OC) & 27 & 27 & 27 & 26 \\
\hline
\end{tabular}

\section{DISCUSSION}

The low diversity of fish fauna recorded in this study may be due to some degree of environmental stress. The controlling factors were probably waste metabolites, such as total organic carbon, silt waste remains and heavy metals. The combined effects of these elements have been known to be responsible for environmental stress (Krebs, 1978; Bucklor et al, 1987). This study indicated that Indomie waste seemed to boost marine production by supplying the required nutrients for primary production through the release of organic metabolites into water column and sediment of the studied environment as adopted in (James and Head, 1972).

The abundant fish species were Cichlidae (Sarotherodon melanotheron and Tilapia guinensis) and Clupidae (Ethmalosa fimbriata and Sardinella maderensis). These species contributed more than $70 \%$ of the identified specimen of fish fauna in the river during the study. Reid et al, (1979) revealed that these groups have adapted to the physical environmental changes in the ecosystem.

Station 3 recorded total number of five species, probably because the fishes avoided areas with heavy organic wastes dumps, clouded by sediments silt/organic remains, low salinity, high concentration of phosphate, and low dissolved oxygen that may be present at the other polluted stations.
The chronic exposure of fish to low levels of chemicals/heavy metals concentrations at high temperature as observed in this study has been known to adversely affect their survival (Pudo and Fubara, 1988; Morgan, 1977). The possible reasons for the survival and well being of the dominant forms may include the fact that the natural water environment contained large volume of water which probably dissolved and diluted the degradable forms of waste. The water was thus dynamic and therefore buffered the impact of the study influx of the toxicants to their tolerable level. Studies of this nature are important in enabling the understanding of the composition of fish populations especially in tropical waters of which little is presently known.

\section{CONCLUSION}

The results of the fish fauna of New Calabar River in Choba investigated have shown that Indomie food industrial effluent is a major source of environmental pollution through the discharge of the effluent into this water body. Elevated levels of these pollution would invariably effect the taste, smell, appearance and aesthetic properties of the water or could pose a potential health hazard of varying degrees to various life forms, which depend on the water for domestic and recreational purposes. Constant treatment of the effluent is recommended. 


\section{REFERENCES}

Ajayi, S. O and Osibanjo, O., 1981. Pollution Studies on Nigeria Rivers 11, Water Quality of some Nigeria Rivers. Environ. Poll. Ser. B. England, pp.87-95, Alpha (1980).

Alam, M. N., Elahi, F., Didar-UL-Alam Md., 2006. Risk and Water Quality Assessment Overview of Rivers Sita Lakhya in Bangladesh. Academic Open Internet J. 19 ISSN 1311-4360.

APHA., 1998. Standard Methods for the Examination of Water and Wastewater $20^{\text {th }}$ Edition, American Public Health Association, Washington DC.

Asuquo, F. E., 1989. Water Quality of the Calabar River, Nigeria. Trop. Ecol. (30): $31-40$

Asuquo, F. E and Okorie, O., 1987. Physicochemical characteristic and Anthropogenic Pollution of the Surface Water of Calabar River, Nigeria. Global J. Pure and Appl. Sci. (30): 31-40.

Bezuidenhout, L. C., Mthembu, C., Duckree, T and Lin, J., 2002. Microbiological evaluation of the Mhlathuze River, Kwazulu-Natal (RSA). Water S.A. 28, (3): 281-286.

Buckler, D. R., Nehrle, P. M. C and Dwyer, F. J., 1987. Influence of $\mathrm{pH}$ on the toxicity of aluminium and other in organic contaminants to East West Coast. Stripedbus. Water, Air and Soil Pollution, (35): 97-106.

Hodgliss, I. J., 1998. Bacteriological monitoring of Hong Kong Marine. Water Quality Environ. Intl. J. 14: 495-499.

James, A and Head, P. E., 1972. The discharges of nutrients from estuaries and their effect on primary productivity, In: Marine Pollution and Sea Life Ed. by Ruivom fishing News, Broks Ltd, London, 624: pp.184.

Krantz, D and Kifferstein, B., 1998. Water pollution and society (online). http://www.umich.edu/ga265/society/wat er pollution.html.
Krebs, C. J., 1978. Ecology, the experimental analysis of distribution of abundance. Harper International Education, New York.

Morgan, W. S. G., 1977. Bio-monitoring with fish, an aid to industrial effluent and surface water quality control program. Water technol. (9): 703-711.

Odokuma, L. O and Okpokwasili, G. C., 1997. Seasonal influences of the organic pollution monitoring of the New Calabar River, Nigeria. Environ. Monitor. Assess. (45): 43-56.

Odukuma, L. O and ljeomah, S. O., 2003. Seasonal changes in the heavy metal resistant bacteria population of the New Calabar River, Nigeria. Global J. Pure and Appl. Sci. 9, (4): 425-433.

Ogan, M. T and Nwuka, D. E., 1993. Studies on the ecology of aquatic bacteria of the lower Niger Delta: Multiple antibiotic resistance among the standard plate count organisms. J. Appl. Bacteriol. (74): 595-602.

Preforious, L., 2000. An investigation into the effect of various levels of sanitation on surface water quality in a typical developing community. SA water bulletin 26, (23): 10-12.

Pudo, J and Fubara, D. M., 1988. Studies on periphyton algae in the petroleum oil spillage areas of the Niger Delta aquatic system. Verb Int. Ver. Limnol, (23): 25592261.

Reid, G. M and Syndenham, D. J., 1979. A checklist of lower Benue River fish and Ichthyogeographical Review of the Benue River (West Africa). Journal of Natural History, (13): 41-67.

Schneider, W., 1990. FAO Identification sheets for fishery purposes. Field Guide to the Commercial Marine Resources of the Gulf of Guinea, FAO ROME: 3-130.

Sinton, L. W., Donnison, A. M and Hastle, C. M., 1993. Faecal streptococci as faecal pollution indicators: A review 11. Sanitary 
significance, survival and use. N. Z. J

Mar. Freshwater Res. (27): 117-137.

Tobor, J. G., 1968. Checklist of the less common marine fishes of Nigeria caught in Lagos trawling grounds. Federal Department of Fisheries Occasional Paper No. (10): 25. 